\title{
Effectiveness of ICT Education in Schools of Journalism in Kenya
}

\section{Tom Kwanya*}

Senior Lecturer, The Technical University of Kenya, Nairobi, Kenya

\begin{abstract}
Information and Communication Technologies (ICTs) are transforming the face of modern journalism. The new tools have great potential in facilitating fast, cost-effective and targeted journalism than the traditional media before them. However, this potential cannot be realized fully if the journalists lack the requisite skills to exploit it. Most schools of journalism have recognized the need to equip their graduates with adequate ICT skills and are already offering regular ICT programmes not only at the undergraduate but also at the graduate levels. Further, there are also a number of online courses and on-the-job training models organized by media houses or journalists' professional associations. In Kenya, however, schools of journalism seemed stuck in time and continued to focus largely on offline journalism. But recently in an attempt to catch-up, these schools have now introduced a number of ICT courses. Using the survey technique this study investigated how effective these ICT courses are. The findings reveal that the courses are not effective.
\end{abstract}

Keywords: ICT journalism; Online journalism; Citizen journalism; Progressive learning; Kenya

\section{Introduction}

Information and Communication Technology (ICT) is the catchall idiom employed to explain a wide array of technologies used in varied extents for gathering, storing, retrieving, processing, analyzing and transmitting information. Common forms of ICT include mobile telephones, computers, as well as networked systems like the Internet and the World Wide Web (WWW), among others [1-4]. Millison [5] defines journalism as any non-fiction or documentary narrative that reports or analyzes facts and events firmly rooted in time (either topical or historical) which are selected and arranged by reporters, writers, and editors to tell a story from a particular point of view. He adds that journalism products have traditionally been published in print, presented on film, and broadcast on television and radio. However, he avers that there is a steady shift from such traditional media to the emerging online media facilitated by ICTs.

Like many other technological developments before it, ICT is rapidly and drastically changing the face of journalism [6-8]. Right from the quill pen which gave way to other pens, and the manual typewriter, which has been replaced by computerized wordprocessors, technologies used for journalism have been numerous through the generations [7]. However, modern ICTs have been used for journalistic purposes since the 1950s though most media houses could not afford the digital tools owing to their prohibitively high acquisition and maintenance costs. Recent commercialization and overall miniaturization of computers and other digital tools have made them much more affordable and usable to support journalistic work in a number of ways $[4,9]$. Journalists are now using various ICT tools to collect, process and transmit news. Such tools include recorders, audio players (iPods), cell phones, digital cameras, laptops, as well as video and audio editing software like Power Director and Video Pad, among other tools. Lately, the WWW and social media have taken the center stage in journalism leading to the rise of the new media concepts such as online journalism, citizen journalism, community journalism, participatory journalism, civilian journalism and collaborative journalism [10] asserts that the Web and the Internet are the mostused new resources for finding online information, replacing and supplementing established commercial services.

Summer [11] asserts that ICTs and other new technologies have had an enormous effect on both the practice and teaching of journalism. Ahiabenu [7] supports this view and argues that ICTs have the potential of enhancing the quality of journalism if used appropriately. Summer [11] also points out further that modern journalists spend more time "on computers and the Internet" making it much easier for them to undertake background research for articles on any topic, search for experts on any topic, and contact them for interviews. Cronery [12] also explains that the Internet in itself is a ready source of stories to fill up unexpected spaces in the media. This makes the reporting process to be quicker and easier than it used to be. Information so gathered is used for feature stories, international news, technology updates, lifestyle magazines, opinion pieces, sports and business news, among other articles.

Chikha [13] asserts that ICTs have now impacted journalistic type-setting, layout, designing and printing of most media products admitting that almost all media institutions are now using some form of ICT to collect, process and produce their products. Satellite and mobile phones have also enhanced communication with reporters and news sources thus facilitating prompt news coverage and filing. Other impacts are evident in marketing of media products which is now more efficient and cost-effective; empowerment of the journalists to work from wherever they are and not necessarily tied to their offices; faster filing and publication of journalistic pieces hence enhancing timeliness and immediacy; globalization of journalistic perspectives and products; and enhancement of professional networks that facilitate professional development and closer relationships with news sources and makers. ICT tools have also enhanced the quality of journalistic pieces by improving media production.

Journalists using ICTs are now able to break news in real-time as it happens through twitter, syndication and mobile phone alerts;

*Corresponding author: Tom Kwanya, Senior Lecturer, The Technical University of Kenya, Nairobi, Kenya, Tel: +254-20-343672; E-mail: tkwanya@yahoo.com

Received July 25, 2014; Accepted September 03, 2014; Published September 10,2014

Citation: Kwanya T (2014) Effectiveness of ICT Education in Schools of Journalism in Kenya. J Mass Communicat Journalism 4: 221 doi:10.4172/2165-7912.1000221

Copyright: (c) 2014 Kwanya T. This is an open-access article distributed under the terms of the Creative Commons Attribution License, which permits unrestricted use, distribution, and reproduction in any medium, provided the original author and source are credited. 
present the story in various media formats (audio, video, text) through podcasts or video blogs; and facilitate seamless and superior interactivity between the users and the journalists [8]. ICTs provide a suitable medium that facilitates instant, ubiquitous, and affordable distribution of media products [5]. ICTs have also enabled journalists to search for information needed to develop stories quickly. This can be done through search engines, bulletin boards, discussion forums, facebook, or blogs in a manner that cannot be rivaled by the traditional media [4,11]. Millison [5] also argues that many more points of view are presented online than offline owing to the freedom of expression as well as lack of restriction on space and time made possible by the use of various ICT tools. Ahiabenu [7] adds that the use of ICTs for journalism boosts journalistic productivity; facilitates global access to journalistic products; supports cost-effective distribution of mass media products; provides platforms for the expression of journalistic creativity, innovation and new opportunities; and reduction of operational costs in media institutions.

ICTs have also impacted journalism negatively. Liu [14] argues that ICTs have increased the workloads journalists now have to bear; trivialized journalistic tasks; intensified managerial control over journalism processes; and degraded journalism as a profession. ICTs have also resulted in job losses among journalists; reduced income from journalism through increased competition from armatures and freely accessible media products; removed essential gates leading to irresponsible journalism; laziness among journalists leading to plagiarism; and information overload leading fatigue.

The potential of ICTs to transform journalism cannot be realized fully if the journalists lack the requisite skills to exploit it. Consequently, there is an urgent need to train journalists on how to make the best use of ICTs for their professional work $[7,8,15,16]$. This could be done by promoting research; academic training and continued training; as well as developing and promoting the digital culture among professional journalists and the society at large [13]. It is also incumbent on journalists to embrace change and accept new journalism tools and approaches. Most schools of journalism all over the world have recognized the need to equip their graduates with ICT skills to enable them to take full advantage of these emerging tools in their work. Indeed, a number of schools are already offering ICT programmes not only at the undergraduate but also at the graduate levels as well. Other training models currently applied include online courses and on-the-job training organized either by individual media houses and/or journalists' professional associations [1,7].

\section{Problem Statement}

As ICTs take the center stage in journalism, most schools of journalism in developed countries are readily embracing ICTs for journalism and introducing suitable courses to impart relevant skills to the students. Conversely, most journalism schools in the developing countries seem stuck in time. In an attempt to catch-up with the rest of the world, the schools are seemingly introducing ICT courses randomly. The situation is exacerbated by the fact that the schools have inadequate ICT tools, information resources and facilitators. Consequently, the students in these schools graduate without the adequate ICT skills that would enable them to use the tools effectively in their practice. Whilst many studies have been conducted on the use of ICTs for journalism, very few have been done on ICT education employed by schools of journalism in developing countries, and particularly in Kenya. In an effort to shed light on this issue, this study sought to establish the presence and delivery of ICT courses in journalism curricula in Kenyan universities and how effective they are in imparting requisite ICTmediated journalism skills to the student-journalists.

\section{Hypothesis}

ICT education offered in schools of journalism in Kenya is not effective in building the capacity of the journalism students to apply ICTs proficiently in journalism.

\section{Objectives}

- To establish the degree of presence of ICT courses in the curriculum of journalism programmes in Kenyan universities;

- To ascertain the level at which the ICT courses are offered;

- To explore the content of the ICT courses offered;

- To establish the major teaching methods used to offer ICT courses;

- To assess the effectiveness of ICT education in schools of journalism in Kenya; and

- To establish any challenges hampering the integration of ICTs in journalism courses in Kenya and make appropriate recommendations.

\section{Research questions}

- How many ICT related courses are taken by an average journalism student in a Kenyan university?

- At what level are the ICT courses offered for journalism students in Kenyan universities?

- What is the general content of the ICT courses offered to journalism students in Kenyan universities?

- What teaching methods are used to deliver the ICT courses offered to journalism students in Kenya?

- Overall, how effective are these courses in imparting requisite ICT skills to the student-journalists?

- What are the challenges faced by Kenyan universities in delivering ICT courses to journalism students and what are their potential remedies?

\section{Theoretical Framework}

This research was prompted by the ubiquity of new media in Kenya which enables it to facilitate real-time access to unregulated content anytime, anywhere, on any digital device and enriched by user feedback as well as creative participation. The author was particularly impressed by the new media theories of remediation, composition and telecommunity which emphasize the role journalists and their audiences play in establishing a thriving communication ecosystem using new media. Whereas the theory of remediation proposes that journalists and audiences should be able to mix and remix new media content, composition theory emphasizes that they should be proficient in ICT processes, systems and tools to do so. As the media actors continue to play their different roles in sustaining the new media ecosystem, telecommunity theory asserts that they can only do so by interacting effectively with technology, the society and among themselves (media) [17].

The theories above propose a wide array of factors and issues that are essential to the creation and sustenance of an effective new 
media ecosystem but the author singled out the technical capacity of journalists. Using progressive learning models such as project-based learning (PBL), active learning, experiential learning and studio-based learning (SBL), the author analyzed the effectiveness of university-level formal training, as one of the capacity building methods, of journalists in Kenya. He also used the learning models to make recommendations on training approaches that can be used to effectively develop the vital skills journalists working in the new media era need.

\section{Literature Review}

The practice of journalism is closely intertwined with technology. Myriad technologies have been applied to journalism over the years. In the recent times, however, computers were the first digital ICT tools to be used actively in journalism in the early 1970s. These early computers in newsrooms were basically mainframe machines used for typesetting and production of newspapers. Computers entered TV and radio broadcasting in the early 1980s. Most of these computers were proprietary machines manufactured by Dynatech Newstar, a pioneer newsroom systems developer, and specifically optimized for newsroom operations [9]. The trend has changed with less proprietary ICT tools finding their way into newsrooms with great success. Consequently, concepts such as computer-assisted reporting, citizen journalism, data journalism, multimedia journalism, content aggregation and fremium ${ }^{1}$ media content models have sprung up to describe the new journalism paradigm which is much more interactive, rich in substance and fast $[4,9]$. ICTs are generally used in journalism for 1) gathering information to be used in news stories; 2) producing newspaper and magazine articles and television or radio newscasts; and 3) distributing news stories and programs to the public or subscribers [9].

Literature reviewed revealed that few theories or conceptual frameworks exist purposely to mainstream the use of ICTs in journalism. Consequently, traditional communication theories are largely being employed to guide the application of ICTs in journalism $[4,7,18]$. Given that these theories were developed for the traditional media, their application to new media is quite restraining. For instance, traditional communication theories generally emphasized control, gate-keeping, rigid processes, defined roles of the audience and sources, and were less converged. All these have been drastically changed in the new media era. In this respect, it is probable that the lack of appropriate theoretical frameworks hampers the effective adoption of ICTs in journalism processes.

The literature review also confirmed that even modern journalists are still deeply traditional. This conservatism seems to stem from the fact that traditional media institutions operate on schedules that have strict deadlines and procedures. Unfortunately, the conservative mindset is still being applied even when journalists use new ICTs. This is demonstrated by the strategies the media houses execute when deploying media products online. For instance, even though ICTs enable people to be virtually connected $24 / 7$, most media houses still operate in the offline paradigm and it is not strange to find a news web site with the time stamp "This site is updated everyday at 12 midnight". This approach restricts the potential of the new media and also the expectations of the users' sense of immediacy $[5,8]$.

The reviewed literature also revealed that though new media may not replace traditional media journalism entirely, the former offers better interactivity and experience for the audiences which may result

${ }^{1}$ This is a new media journalism model in which some basic content products are given free while premium quality ones are offered to those who are interested at a fee. It combines the words "free" and "premium". in most people preferring them to the latter [5,7]. This trend has already begun as audiences move online and carry along with them advertising which is the core revenue stream for the traditional media business model. These emerging trends demand collaboration between the new and traditional media to harness the synergy between the two and deliver more enhanced media platforms and products [5] warns that print publications, especially, may lose customers to $\mathrm{Web}$ publications if they don't find new ways to deliver news and information as well as services to those Web-savvy customers in print as well as on the Web.

It is also evident from the reviewed literature that the modern journalist needs to be multi-skilled $[10,18]$. Journalists who blend the traditional and new journalism knowledge-bases are becoming more successful [8]. The literature also reveals that some of the ICT skills desirable for modern journalists include proficiency in common computer applications, basic Web publications design, basic HTML and Cascading Style Sheets (CSS) coding, use of common content management systems and social media platforms, database management, digital audio and video production, Webcasting (podcasting and video casting), infograhics (data visualization), and Web scripting, among other skills to enable the journalists to embed multimedia elements to media products which are delivered through ICT channels $[5,19,20]$.

The literature review also revealed that there are many hurdles that hamper the full realization of the potential of ICTs for journalism, especially in the developing countries. Some of these include: One, shifting the operations of the newsroom from what it currently is to a 24-hour paradigm cannot happen in one day. There are organizational challenges to it besides costs. Most media institutions, especially in the developing countries, have limited resources making it difficult for them to move their services online. Two, most of the newsrooms are full of journalists trained in the offline paradigm and lack requisite skills to make meaningful use of new ICTs. This is one of the biggest challenges [4]. Three, inadequate ICT and associated infrastructure, both at the institutional and national levels, also hampers progress in domesticating ICTs for journalism. Four, most media institutions do not have ICT policies that can stimulate the use of these tools in the "newsroom"2 leading to disjointed and disparate use of the tools [7]. Five, most countries lack comprehensive online journalism policies and guidelines. This loophole can be abused by both journalists and authorities in such ways that hamper the development of ICTfacilitated journalism [8]. Six, journalists view the emerging ICT channels as being too embedded in entertainment to provide a good platform for serious journalism [4].

It is also evident from the literature review that the use of ICTs for journalism may also hamper the growth of the profession in certain respects. One of the issues that emerge in this strain of thought is the quality of content delivered on ICTs which is considered as questionable since anyone can become an online author [5]. Other issues include over-reliance on technology; the WYSIWYG (what you see is what you get) culture which over-simplifies the publishing process and thus reduces the opportunities for creativity; and revenue loss due to freebies expected by online users. Such losses limit the capacities of media houses to invest in proper training of the journalists, quality assurance processes as well as other critical journalistic processes that would enable the institutions and the profession to grow [4].

It is also clear from the literature that the future-journalism will rely more on ICTs than traditional media do at the moment.

${ }^{2}$ This term is used here to imply core journalism functions. 
Furthermore, the pace of domestication will become even more rapid as extensive progress in the ICT sector enables digital devices and high speed broadband to become more ubiquitous and affordable. With more people interacting and transacting online, the media will need to migrate online as well to tap this growing audience segment [4]. To make this possible, good, reliable editing and filtering of information becomes ever more important on the Web. Similarly, journalists will continue to experiment with the emerging media on how best to maximize their potential for journalism [7]. The ultimate outcome of this trend will be media products for audiences of one, completely personalized according to individual preferences, served out of large editorial databases or assembled on the fly by intelligent agent software that scans the Web for news and information that meet the individual's profile of interests [5].

\section{Methodology}

This study applied the survey research methodology in which self administered questionnaires were circulated to journalism students at the University of Nairobi, main campus; United States International University-Africa; Daystar University, Nairobi campus; and Moi University, Nairobi campus. The researcher was assisted in this process by current students of the respective schools of journalism who distributed the questionnaires randomly to all students who were willing to respond. A total of 150 questionnaires were circulated of which 78 were returned. The researcher also reviewed the course descriptions of the journalism programmes in these schools.

\section{Findings}

\section{Respondents by university}

There were significantly more respondents (Figure 1) from the University of Nairobi. This can be attributed to the fact that the university possibly has more journalism students than the other universities. Perhaps, the high number of journalism students at the University of Nairobi can be explained by the fact that the university hosts the oldest school of journalism in Kenya. Indeed, the School of Journalism (SOJ) at the University of Nairobi was established as a UNESCO project in 1968 and remains a top journalism training center in East and Central Africa. To date, the school has the highest number and frequency of intakes in Kenya. The number of respondents, however, is not an accurate representation of the actual ratios of journalism students in the universities.

\section{Respondents by year of study}

There was a higher response rate among the senior students

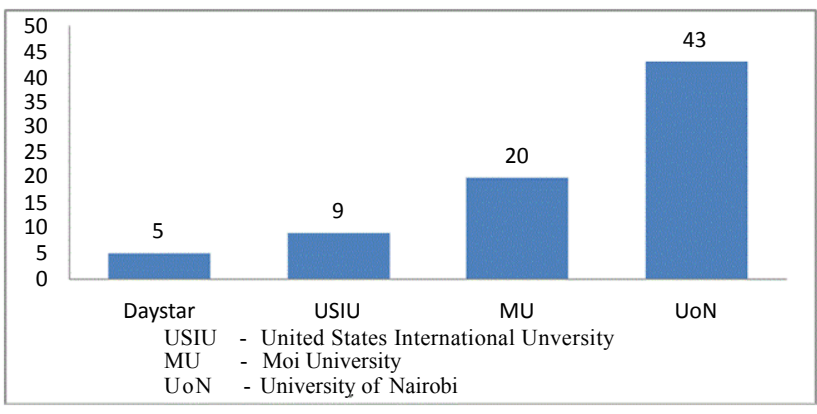

Figure 1: Respondents by university.

Source: Researcher

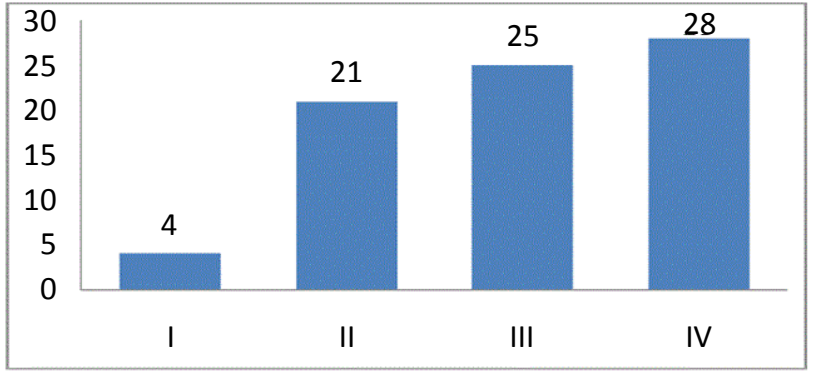

Figure 2: Respondents by year of study.

Source: Researcher

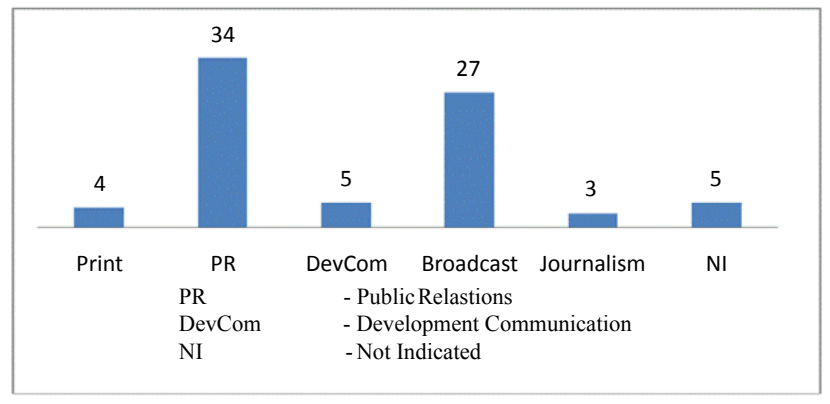

Figure 3: Respondents by major.

Source: Researcher

(Figure 2). This response rate is the reverse of what would ordinarily be expected-that first year students have more time to respond to questionnaires than the senior students. However, these findings can, perhaps, be attributed to higher levels of awareness among the senior students as well as their growing interest in research. It is also possible that some of them may have already begun conducting their final research projects. The junior students, on the other hand, may be struggling to settle down and are yet to get integrated into the research culture at their respective schools.

\section{Respondents by “Major”}

There were significantly more responses from students specializing in Public Relations (44\%), followed by those specializing in broadcast media (34\%). The other specializations scored under 8\% (Figure 3). The high response rate from the students majoring in Public Relations may be attributed to the nature of their training and perhaps their personality traits. PR students are generally more outgoing, more aware of their surroundings and seeking to build relationships in the schools and beyond than their counterparts in the other disciplines. This attitude basically exposes them more to such research projects which they ordinarily respond to.

These findings could also be indicative of the possible fact that the schools have more students majoring in Public Relations and broadcast media than the other majoring disciplines. The preference for these majors can be attributed to the job market trends as well as the perceived prestige associated with the practice of the same. Given that Public Relations is a fairly young profession in Kenya, it is still popular with many students. It is also perceived to expose the students to more and better-paying job opportunities than the others. Broadcast 
journalism, on the other hand, is generally preferred due to its celebrity perception. Most students choose it so as to develop their talents and be like some professional "idols" they admire and basically to hear their voices on radio or see their faces on television.

\section{Courses offered}

The findings reveal that most ICT courses are offered in the first and second years. Some of the common ICT courses include:

Introduction to computer: This course is generally offered at the junior level and covers topics such as basic computer operations, basic computer hardware and software, history of computers, parts of a computer; and types of computers. The major skills obtained from this course include basic computer operation, differentiation between various computer software and general understanding of computer terminology. This course seems to have been developed before computers became more ubiquitous. It seems to have been developed to introduce computers to the students who were new computers. It is now definitely obsolete in most respects as most students are now either born with computers or have acquired them before joining universities.

Computer applications: This course is also offered at junior level and basically introduces the students to computer software applications such as operating systems and various applications. However, the focus is basically on developing proficiency of the students in the Microsoft Office suite. Consequently, the skills obtained from this course include word-processing, PowerPoint presentations and general document formatting.

Fundamentals of ICT: This course is offered in junior level and generally focuses on defining ICT, history of ICT, general uses of ICT, and uses of ICT in communication. The skills obtained include proficiency in the effective use of email, surfing the Web, conducting research on the Internet as well as general understanding of ICT concepts and terminologies.

New ICTs: This is a variant of "Fundamentals of ICT" above and focuses on ICT tools such as the Internet, Intranets, mobile telephony, the World Wide Web and their possible uses in journalism. The skills obtained generally revolve around the application of ICTs to communication.

Online journalism: This course is offered at senior level and is aimed at equipping the students to apply online tools in journalism. The findings reveal that various schools have different approaches to this course. However, the general focus seems to be on Web design. Further, it is generally offered theoretically in most schools. Where it is offered practically, the students undertake Web design projects which encompass the whole spectrum of Web publishing skills including writing for the Web, Web publishing ethics, Web graphics management as well as building proficiency in the use of HTML editors such as Macromedia Dreamweaver and Microsoft FrontPage. It is, however, offered as an elective course.

Communication and technology: Offered at senior level, this course basically covers the application of various technological tools to communication. The primary focus is on ICT policies, the digital divide and the needs and characteristics of the information society. It is also an elective course.

Management of IT: This course is also offered at senior level and is aimed at equipping the students to capably manage ICT systems and projects. It is a general IT course with little focus on communication per se.
The researcher also wishes to point out that apart from the introductory courses, the others are all elective courses offered within the majors. For instance, at the University of Nairobi, Online Journalism is an elective course offered to broadcast media students while Communication and Technology is also an elective at the same university offered to development communication students. At USIU, however, online journalism is an elective course but available to all the journalism students [21].

\section{Mode of teaching}

The findings reveal that most of the courses are taught theoretically (Figure 4). About $62 \%$ of the respondents indicated that the ICT courses they have taken so far focused more on theory; only about $5 \%$ of the respondents had taken practical ICT courses. However, it is worth noting that $27 \%$ of the respondents indicated that some level of balance is being attempted in some instances. $6 \%$ of the students did not provide a response to this question. This is perhaps an indication that they did not hold a strong view further implying that they may have not been sure of the true response.

\section{Background of lecturers}

The study also reveals that most (43\%) of the lecturers teaching ICT courses in the schools of journalism in Kenya have an ICT background. It is noteworthy that only a small minority (25\%) have a journalism background. However, the backgrounds of a sizable portion (31\%) of the lecturers is unknown to the students. Assuming that all the lecturers with unknown backgrounds are not from journalism, it implies that $74 \%$ of the lecturers come from outside the profession (Figure 5).

\section{Skills obtained}

In summary, the respondents indicated that they obtained the

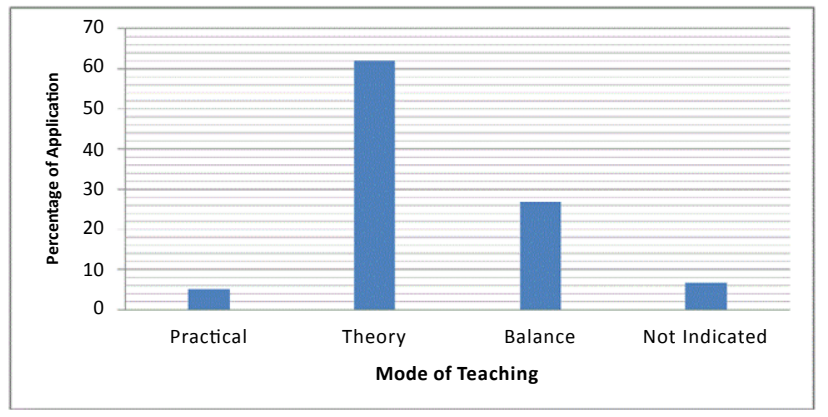

Figure 4: Mode of teaching.

Source: Researcher

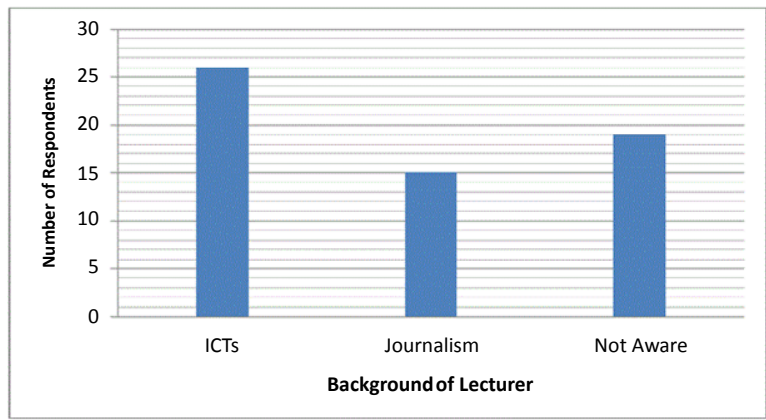

Figure 5: Background of lecturer. Source: Researcher 
following skills from the ICT courses they took:

- Understanding of computers and how they operate, computer components, computer peripherals, and management of computers;

- Web design and publishing;

- Understanding of ICT security threats such as spamming or hacking and how to prevent them;

- Understanding of the salient issues about the Internet including its threats and opportunities for journalism and communication;

- Online information searching and retrieval;

- Creation and use of blogs;

- Etiquette observed when using various ICT tools such as email or mobile phones for inter-personal communication;

- ICT legislations and policies;

- Desktop publishing; and

- Microsoft Office proficiency.

It is critical to note that 11 (about $14 \%$ ) of the respondents frankly admitted that they received nothing much from the ICT courses they took. 3 (about 4\%) also stated that they would not need the ICT skills they obtained in their professional practice of journalism. The rest of the students said that they would use the skills obtained from these courses in the following ways:

- Apply the skills in ICT journalism;

- Consultancy;

- Provide basis for pursuing further courses in ICT and related disciplines;

- Gathering news;

- Knowing what computer hardware and/or software to buy and how to install the same;

- Organizing PR events; and

- Data management and manipulation.

\section{Likes and dislikes}

The students stated they liked:

- The practical sessions;

- The interesting, enjoyable and educative course content; and

- Relating the courses to real-life issues facing journalists on a day-to-day basis.

Still 5 (about 6.5\%) respondents said they liked nothing about the courses. Asked about what they disliked about the courses, 29 (about $40 \%$ ) said they abhorred lack of practical sessions and the resultant focus on theory. 3 (about 4\%) respondents also disliked the use of complicated jargon. Other outstanding dislikes include the following (quoted verbatim):

- "The lecturers taught practical classes through imagination";

- "Everything, I hate ICTs";
- "Too difficult if one doesn't have a background in computers";

- "Too involving and time consuming"; and

- "Courses were not detailed".

\section{Challenges}

35 (about 45\%) identified inadequate ICT facilities (computers, Internet access, and other ICT tools) as the major challenge to effective ICT training in the schools. Other challenges identified include:

- Inadequate time allocation for ICT courses;

- Inadequate ICT information resources such as books; and

- Inadequate lecturers giving shallow unorganized lectures and notes.

The other challenges are summarized hereunder verbatim:

- "Slow Internet services in ICT labs";

- "The computer lab was too small”;

- "Computers too slow";

- "Lecturer absenteeism";

- “Outdated ICT programs";

- "Computer viruses";

- "Unqualified lecturers"; and

- "Frequent computer breakdowns".

\section{Recommendations}

29 (about 40\%) of the respondents suggested that the schools should improve ICT infrastructure by acquiring more computers and a stable Internet connectivity. Other conspicuous recommendations include:

- Offer more practical lessons (30\%);

- Engage qualified lecturers (20\%);

- Allocate more time for ICT lessons and make them compulsory $(18 \%)$; and

- Encourage the students to create their own online discussion groups (3\%).

Other verbatim recommendations were as follows:

- "More cost-friendly books";

- "Balance theory and practical";

- "Offer online education or distance learning";

- "Basic training should be offered to students without the knowledge of computers, not to all the students";

- "Expand the scope of ICT lectures";

- "Customize the courses for communication";

- "Lecturers should use real-life examples"; and

- "Courses should be based on current ICT trends." 


\section{Discussion}

\section{ICT related courses taken by an average journalism student in a Kenyan university}

It is evident from the findings that there is no school of journalism in Kenya which offers ICT/Online Journalism as a specialization. ICT courses are offered either as part of the general education courses or as electives. Although the ICT courses seem to be many, a keen analysis reveals that they can comfortably be lumped up into three courses as below:

- Introduction to computers-Introduction to computers, computer applications, fundamentals of ICT, management of IT;

- ICTs and communication-New ICTs, ICT and communication and

- Online journalism.

This finding implies that on average, a student-journalist in Kenya takes about one substantive ICT course during the entire degree programme. Undoubtedly, one ICT course cannot be adequate to empower them to use the dynamic ICT tools effectively for journalism. Consequently, the students graduate without the requisite ICT skills and may perhaps be forced to take ICT courses after college. Obviously, this makes the journalism training in Kenya to be more expensive and largely outdated. It is incumbent on the relevant authorities to address this gap by introducing more substantive ICT courses in the journalism curricula. Each of these courses should build on each other and be aligned to a specific ICT skill-base needed for modern journalism. For instance, broadcasting students could take courses that build their capacity to embrace digital multimedia production, for instance, through podcasting and video casting.

\section{The levels at which ICT courses are offered to journalism students in Kenyan universities}

Most of the ICT courses are taught at the junior levels and as noted earlier, they are taught as part of the general education courses [22]. This approach affects their effectiveness in a number of ways:

- General education classes are generally larger than the core professional courses. This implies that they exhibit lower student-to-lecturer ratios. The low ratios reduce the levels of lecturer-student and student-student interactions and thus affect the learning process negatively. Similarly, the studentto-computer or other ICT tools ratio is equally low. This is corroborated by the fact that the students identified lack of computers and small laboratories as some of the major hindrances to effective ICT training. Given that the progressive learning theorists suggest that classes ought to be small for effective learning to occur, the general education environment is not conducive for practical-oriented ICT training.

- Given that the general education courses are offered at junior levels before the students get a good understanding of journalism, the students tend to forget the skills by the time they need to apply them in real-life journalism assignments and discourse in senior years and after graduation. It would be prudent to spread the courses throughout the lifespan of the programme. Modern learning theories recommend learning cycles which give the learners ample opportunity to reflect upon what they have learned and apply it appropriately in real life scenarios. This is not possible if all the courses are lumped up in one section of the program as the case is at the moment.

- Students do not take general education courses seriously as they view them as additives to fill the time-table and keep them in college longer and justify the four-year schedules. They also perceive such courses as less important. Undoubtedly, this attitude affects their learning. Consequently, offering most ICT courses at this level grossly undermines their effectiveness.

- Students in their junior years ordinarily take many courses leaving them with less time to experiment, research and practise what they learn. Effective learning requires giving the learners an ample opportunity to apply and internalize the knowledge. Otherwise, the skills get easily replaced by new knowledge which may be perceived as critical for the moment through an "un-learning" process. It is unfortunate that the few ICT skills obtained through the courses may be unlearned as soon as they are acquired.

\section{The content of the ICT courses offered to journalism students in Kenyan universities}

Apart from the number of courses being insufficient, the content is also inadequate. Again, it is noteworthy that the courses are very general in nature and are only suitable for introductory levels. Owing to the nature of the ICT skills desirable for journalists, indepth courses on areas such as social media techniques and tools, writing for the Web, Web design, HTML coding, basic Web scripting, multimedia production, photo editing, citizen journalism, Internet radio production and podcasting could equip the students better with the fundamental skills to exploit the potential of ICTs for journalism fully. Most of the courses, as currently offered, do not present the right depth of content. Consequently, students come out claiming to have taken ICT courses but with narrow or irrelevant skills which cannot be applied in journalism. No wonder some students asserted that they will not apply any of the ICT skills they have learned in journalism practice! The quality of knowledge acquired through learning is significantly determined by the depth of the course content. It would also be prudent to program the courses so that they build the skills incrementally. At the moment they seem to be offered haphazardly; no course seems to lead to or build on another. Conversely, they seem like independent modules that exist purely on their own and offered with no logical foundation.

\section{The teaching methods used to deliver the ICT courses offered to journalism students in Kenya}

This is one area where the students expressed serious dissatisfaction. Technology can be very complicated and intimidating even to born "ICT natives". It is critical that these trainings be offered in ways that facilitate experimentation and practical learning. As project-based learning proposes and recommended by the respondents, the lecturers should apply real-life examples and give the learners an opportunity to solve them. This approach would capture the students' attention and stimulate analytical thinking about the challenges that face journalism and how to apply ICTs to effectively mitigate them. Furthermore, because of the complexities surrounding technology, some of the concepts are very abstract if not represented practically. This approach facilitates learning by doing and simplifies the concepts thus enhancing the quality of learning. Further, what the students learn by doing has a higher potential of recall which is also an important element of effective learning [23-25]. 
The role of the facilitator in a learning process cannot be overemphasized. The research findings reveal that most of the lecturers have ICT backgrounds. This implies that they are very "technical". This could, perhaps, explain why some of the students stated that the ICT courses they took were too complicated and laden with sophisticated jargon. The background of the lecturers may also be blamed for apparent non-alignment of the courses to journalism or communication. The lecturers with ICT backgrounds are most likely to focus only on the technical aspects of ICT and thus miss out on their application to journalism. Even where this approach succeeds in imparting ICT skills, such skills are normally irrelevant to journalism.

ICT is a dynamic discipline in which tools and techniques are constantly changing. It is important, therefore, that ICT courses are not used as ends in themselves. For instance, developing competency in specific computer applications should not be the ultimate goal in effective ICT learning because such skills would be obsolete as soon as the application is replaced or upgraded. Facilitators should therefore teach fundamental principles the specific applications exemplify as a way of preparing the students to use any tools or techniques which may emerge in the future. Emphasizing specific application training is like coaching construction students how to use specific tools such as hammers instead of teaching them how to build and letting them choose an appropriate tool in their contexts. Similarly, this approach would stimulate creativity among the learners as each of them seeks innovative ways of solving prevailing journalism challenges without being fixated to specific ICT applications or platforms.

\section{The challenges faced by Kenyan universities in delivering ICT courses to journalism students and what are their remedies}

The main challenge facing schools of journalism in Kenya in ICT education is inadequate infrastructure. Whilst most of the schools have invested in broadcast production studios, many of them have not invested adequately in computer laboratories. Even where the laboratories exist, they are too small, understaffed or stocked with obsolete equipment. It is also important to note that Internet connectivity is now an important part of ICT infrastructure in any journalism school and requires due recognition. Appropriate investment in ICT infrastructure is paramount for effective training of future journalists. The Kenya Education Network Trust (KENET) offers subsidized access to the Internet for educational institutions in Kenya. It also has some funds from donors such as the World Bank to improve ICT infrastructure in universities and other tertiary institutions of education in Kenya. The schools of journalism should develop appropriate proposals to access these funds. Furthermore, with the recent landing of fiber optic networks-SEACOM and TEAMS-the costs of broadband Internet connectivity will reduce drastically. The schools should take advantage of these opportunities and equip the laboratories adequately.

Developing specialized curricula for journalism using ICTs as an area of specialization would also go a long way to enhancing the quality of ICT education in the schools. Such specialization would ensure that there is adequate time to deliver in-depth and relevant ICT content. It would also provide adequate time for practical sessions than is currently possible. Nonetheless, the schools should revise their curricula and introduce more ICT courses even for students who may not choose such a specialization.

There are few qualified ICT journalism lecturers with a communication or journalism backgrounds in Kenya. This is largely because the graduate journalism programmes do not offer adequate
ICT courses. To build capacity in the long term, the schools of journalism should revamp the graduate programmes to include ICTs. Thus, the students who graduate from such programs would be able to conduct lectures of ICT courses effectively. Offering short courses as part of continuing education may also help. Such courses could be offered through the professional organizations such as the Kenya Union of Journalists, the Editors' Guild, Public Relations Society of Kenya or Media Council of Kenya and may be useful especially for the journalists who graduated before ICT made remarkable inroads in journalism. The courses may contribute greatly in mainstreaming ICTs in the newsrooms given that such journalists are currently in senior management positions in most media institutions.

The students also expressed the difficulty of getting adequate information resources and other ICT learning aids. Indeed, there are very few books discussing the application of ICTs to journalism. Consequently, most of the lecturers just recommend general ICT books in their reading lists. Sadly, these books are not just irrelevant, they are also complicated. Besides, they are also not easy to get in Kenya. In the short-term, the schools should develop appropriate library collection on this theme even if it is composed of just a few copies which the students can share. At the same time, there are many good information resources online. The lecturers should review the resources and make recommendations on what is adequate. Such recommended resources should form part of the reading materials which could be delivered in an online platform. The schools should also encourage and sponsor research papers on various pertinent issues and avail the publications or research reports to their students. The schools may also organize conferences on diverse ICT and journalism themes and commit to publish the presented papers and reports of the deliberations. These could be some of the easiest and perhaps most affordable ways of developing high quality and customized publications on this theme.

Peer education is renowned for its effectiveness in imparting skills on almost all spheres of knowledge and life. Therefore, a good way of enriching any learning process is to encourage interaction among the students to enable them to share ideas and experiences. These interactions enable the students to discuss their learning challenges freely with their colleagues and bridge the existing gaps. The curricula should be revised to make provisions for collaborative and/or cooperative learning. There are many electronic learning resources that can facilitate this. If acquiring fully-fledged electronic learning systems is expensive, the schools could seek free and more affordable options using free Web 2.0 utilities.

\section{Conclusion}

The findings indicate that ICT courses offered in the schools of journalism in Kenya are not effective in imparting the requisite knowledge to empower the students to use ICT tools for journalism and communication work effectively. Thus the hypothesis has been endorsed. Given that ICTs have become crucial tools for journalism, it is incumbent on the schools to revise their curricula and introduce or enrich courses that will ensure that the student-journalists are adequately trained in ICTs. Most schools of journalism in the developed countries have already adopted ICTs and are offering various courses on the theme. The schools of journalism in Kenya, and by extension the rest of Africa, cannot afford to be left behind. Otherwise, their students would be disadvantaged in the global arena. It would also impact on the amount and quality of news on Africa in cyberspace and other related media. This is the time to act and redeem the situation. 
Citation: Kwanya T (2014) Effectiveness of ICT Education in Schools of Journalism in Kenya. J Mass Communicat Journalism 4: 221 doi:10.4172/21657912.1000221

Page 9 of 9

\section{References}

1. Newhagen JE, Levy MR (1998) The future of journalism in a distributed communication architecture. In: The electronic grapevine: rumor, reputation and reporting in the new online environment. Mahwah: Lawrence Erlbaum.

2. Kraut R, Mukhopadhya T, Szczypula J, Kiesle S, Scherlis B (1999) Information and Communication: alternative uses of the Internet in households. Information Systems Research 10: 287-303

3. Selwyn N (2003) Apart from technology: understanding people's non-use of information and communication technologies in everyday life. Technology in Society 25: 99-116.

4. Kwanya T (2009) ICT simplified: a handbook for the communication worker Nairobi: Focus Publishers.

5. Millison D (2004) Online Journalism FAQ.

6. Bardoel J, Deuze M (2001) 'Network Journalism': converging competences of old and new media professionals and Professionalism. Australian Journalism Review 23: 91-103.

7. Ahiabenu K (2007) Introduction to ICT journalism.

8. Rambau H (2007) The role of ICTs in journalism.

9. Hanson G (2006) Journalism.

10. Garrison B (2001) Diffusion of online information technologies in newspaper newsrooms. Journalism 2: 221-239.

11. Summer D (2006) Journalism and ICT.

12. Cronery D (2007) Assessing the contribution of Internet as a source of news and information to the print media industry in Tanzania.
13. Chikha YB (2007) ICT and journalism development in Tunisia

14. Liu C (2006) De-skilling effects on journalists: ICTS and the labour process of Taiwanese newspaper reporters. Canadian Journal of Communication.

15. Mitchell J, Henry J, Young S (2001) Work-Based Learning in the Contemporary Australian VET Sector: A Re-Appraisal.

16. Mitchell J, McKenna S (2008) Action learning and the national training system

17. Theories of learning (2002) Oxford Centre for Staff and Learning Development (OCSLD).

18. Cottle S, Ashton M (1999) From BBC Newsroom to BBC Newscentre: on changing technology and journalist practices. Convergence: The International Journal of Research into New Media Technologies 5: 22-43.

19. Bull A (2010) Multimedia journalism: a practical guide: Routledge.

20. Gray J, Bounegru, L Chambers L (2011) The data journalism handbook: How journalists can use data to improve the news: O'REILY.

1. Hawke C, Martin G (2000) Much more than a ripple on the surface: an evaluation of the Professional Development Support Program in Western Australia, 199799. Dept. of Training and Employment.

22. McGill I, Beaty L (1995) Action Learning: a guide for professional, management and educational development. London: Kogan Page.

23. Action Learning Associates International (ALA).

24. Skippington P (2002) Learning@Work. Good practice in workbased learning case studies of Reframing the Future projects. Brisbane, Queensland: ANTA.

25. Zuber-Skerritt O (2001) Action Learning and Action Research: paradigm, praxis and programs. 